DOI

\author{
ТЕРНОПІЛЬСЬКИЙ ДЕРЖАВНИЙ МЕДИЧНИЙ УНІВЕРСИТЕТ ІМЕНІ І. Я. ГОРБАЧЕВСЬКОГО
}

\title{
ВПЛИВ УРАЖЕННЯ АЦЕТАМІНОФЕНОМ НА ТЛІ ЦУКРОВОГО ДІАБЕТУ ТИПУ 2 НА ЗМІНИ ПОКАЗНИКІВ ГЛУТАТІОНОВОЇ СИСТЕМИ
}

Вступ. Найважливішою фрункцією печінки в організмі є нейтралізація і знешкодження токсичних речовин. Метаболізм та утилізацію хімічних і біологічних токсинів здійснює знешкоджувальна система гепатоцитів з подальшим виведенням шкідливих продуктів з організму.

Мета дослідження - вивчити вплив ацетамінофену на тлі цукрового діабету типу 2 на основні параметри глутатіонової ланки антиоксидантної системи в гомогенаті печінки щурів у часовій динаміці.

Методи дослідження. Досліди проводили на білих статевозрілих щурах масою тіла 180-220 2, яких утримували на стандартному раціоні віварію при вільному доступі до води. Було виконано 2 серії експериментів. У першій токсичне ураження ацетаміносреном викликали иляхом одноразового внутрішньошлункового введення тваринам суспензії ацетамінофену в 2 \% розчині крохмалю у дозі 1250 мг/кг маси тіла $\left(1 / 2 L D_{50}\right)$, у другій - суспензії ацетамінофрену в 2 \% розчині крохмалю у дозі 55 мг/ке, що відповідає вищій терапевтичній дозі, протягом 7 діб. Негенетичну форму експериментального цукрового діабету типу 2 моделювали за методикою S. Islam, H. Choi (2007) шляхом одноразового внутрішньочеревного введення

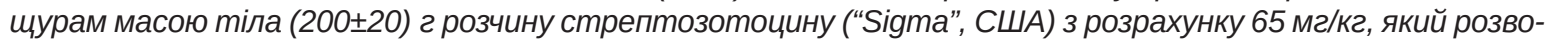
дили цитратним буферем (рН 4,5), з попереднім (за 15 хв) інтраперитонеальним уведенням нікотинаміду в дозі 230 мг/ке. Для контрольної групи використовували щурів з тією ж масою тіла, яким вводили аналогічний об'єм розчинника (цитратний бусрер із рН 4,5).

Результати й обговорення. Активація реакцій ліпідної пероксидації є одним із фрундаментальних біологічних механізмів пошкодження біоструктур і розвитку клітинної патології при дії пошкоджувальних фракторів різного генезу, особливо за умов дії ксенобіотиків.

Висновок. Отруєння ацетамінофеном на тлі цукрового діабету типу 2 спричиняє істотне порушення компенсаторних механізмів, особливо стану фрерментної та неферментної ланок антиоксидантної системи.

КЛЮЧОВІ СЛОВА: ацетамінофен; відновлений глутатіон; глутатіонпероксидаза; глутатіонредуктаза; цукровий діабет.

ВСТУП. Найважливішою функцією печінки в організмі є нейтралізація і знешкодження токсичних речовин. Метаболізм та утилізацію хімічних і біологічних токсинів здійснює знешкоджувальна система гепатоцитів з подальшим виведенням шкідливих продуктів з організму [1, 2]. Однак деякі речовини, в тому числі лікарські середники, в результаті цих перетворень стають ще більш гепатотоксичними, ніж самі фрармпрепарати (так званий “летальний синтез"), тому тривале приймання таких медикаментів призводить до виснаження знешкоджувальної системи печінки і пошкодження гепатоцитів [3].

Цукровий діабет (ЦД) - це хронічне ендокринне захворювання [4]. Проблема цукрового діабету дуже гостро стоїть не тільки в нашому (с) О. Б. Фурка, 2017. суспільстві, а й у світі в цілому. Кожна 9-та людина страждає від цього захворювання, з них 15-20 \% - діти.

На сьогодні відомо багато найменувань лікарських препаратів, які містять ацетамінофен та використовуються переважно як жарознижувальні засоби. Люди із цукровим діабетом також часто застосовують ці препарати [5-8].

Зважаючи на наведені вище факти, доцільно дослідити стан глутатіонової ланки антиоксидантної системи в щурів з токсичним ураженням ацетаміносреном на тлі цукрового діабету типу 2.

Мета дослідження - вивчити вплив ацетаміносрену на тлі цукрового діабету типу 2 на основні параметри глутатіонової ланки антиоксидантної системи в гомогенаті печінки щурів у часовій динаміці. 
МЕТОДИ ДОСЛІДЖЕННЯ. Досліди проводили на білих статевозрілих щурах масою тіла 180-220 г, яких утримували на стандартному раціоні віварію при вільному доступі до води.

Було виконано 2 серії експериментів. У першій токсичне ураження ацетаміносеном викликали шляхом одноразового внутрішньошлункового введення тваринам суспензії ацетамінофену в $2 \%$ розчині крохмалю у дозі 1250 мг/кг маси тіла $\left(1 / 2\right.$ LD $\left._{50}\right)$, у другій - суспензії ацетамінофену в $2 \%$ розчині крохмалю у дозі 55 мг/кг, що відповідає вищій терапевтичній дозі, протягом 7 діб. Негенетичну форму експериментального цукрового діабету типу 2 моделювали за методикою S. Islam, H. Choi (2007) шляхом одноразового внутрішньочеревного введення щурам масою тіла (200 \pm 20$)$ г розчину стрептозотоцину ("Sigma", США) з розрахунку 65 мг/кг, який розводили цитратним бусрером ( $\mathrm{pH} 4,5)$, з попереднім (за 15 хв) інтраперитонеальним уведенням нікотинаміду в дозі 230 мг/кг [9]. Для контрольної групи використовували щурів 3 тією ж масою тіла, яким вводили аналогічний об'єм розчинника (цитратний бусер із $\mathrm{pH} 4,5$ ).

У першій серії експериментів піддослідних щурів поділили на 4 групи: 1-ша - інтактні (контроль); 2-га-уражені ацетамінофреном одноразово; 3-тя - тварини, яким вводили стрептозотоцин; 4-та - уражені ацетамінофеном одноразово після введення стрептозотоцину. В другій серії експериментів піддослідних тварин поділили на 4 групи: 1-ша - інтактні (контроль); 2-га уражені ацетаміносеном протягом 7 діб; 3-тя тварини, яким вводили стрептозотоцин, 4-та уражені ацетамінофеном протягом 7 діб після введення стрептозотоцину.

Тварин виводили з експерименту на 1-шу, 3-тю, 5-ту та 7-му доби з моменту припинення ураження шляхом евтаназії за умов тіопенталового наркозу. Всі експерименти на щурах проводили відповідно до Науково-практичних рекомендацій з утримання лабораторних тварин та роботи з ними [10].

Активність глутатіонпероксидази (ГП) та глутатіонредуктази (ГР), а також вміст відновленого глутатіону (ВГ) визначали в гомогенаті печінки $[11,12]$. Кількісні показники обробляли статистично. Результати досліджень піддавали статистичному аналізу [13] за допомогою статистичної програми Statistica 6.0. з використанням параметричного критерію Стьюдента та непараметричного критерію Вілкоксона для зв'язаних вибірок. Зміни вважали достовірними при $p \leq 0,05$.

РЕЗУЛЬТАТИ Й ОБГОВОРЕННЯ. АКТИВація реакцій ліпідної пероксидації є одним із фунда- ментальних біологічних механізмів пошкодження біоструктур і розвитку клітинної патології при дії пошкоджувальних факторів різного генезу, особливо за умов дії ксенобіотиків. Прикладом пошкодження клітинних мембран внаслідок утворення продуктів ліпопереокиснення $€$ також гемоліз еритроцитів, що настає в результаті недостатності генератора НАДФН, необхідного для фрункціонування глутатіонредуктази і підтримання глутатіону у відновленій формі.

Глутатіон є центральним компонентом антиоксидантних систем майже всіх клітин і органів. Його антиоксидантна дія пов'язана з перенесенням сульсргідрильних груп. При роботі глутатіонпероксидази він перетворюється на дисульфрід, і тим самим відбувається знешкодження продуктів ліпопероксидації. Глутатіонредуктаза переводить глутатіон у відновлену форму. Активність глутатіонпероксидази в організмі багато в чому визначає динаміку патологічних процесів. При зниженні активності глутатіонпероксидази порушується захист клітин печінки від небезпечних хімічних речовин.

Як показали отримані результати, можна стверджувати, що в першій серії експериментів глутатіонова система при ураженні тварин ацетамінофреном на тлі цукрового діабету типу 2 зазнає виснаження (табл. 1).

Відновлений глутатіон зазнав максимального зниження на 1-шу добу експерименту в усіх групах піддослідних тварин: при гострому токсичному ураженні ацетаміносреном (2-га група тварин) він зменшився на 40,7 \%, при ЦД типу 2 (3-тя група тварин) - на 12,7 \%. Застосування $1 / 2$ LD $_{50}$ ацетамінофену на тлі цД типу 2 (4-та група тварин) призвело до ще більшого зниження даного показника - на 67,3 \% відповідно до контрольної групи щурів. Отже, дані результати показують, що більшу токсичність викликає введення ацетамінофрену на тлі ЦД типу 2, що призводить до різкого зменшення вмісту ВГ. У подальшому експерименті цей показник зазнавав поступового відновлення. На 7-му добу експерименту він становив уже $72,5 \%$ у 2-й групі тварин, 44,7 \% - у 4-й групі, тоді як у 3-й групі нормалізувався. Слід відмітити, що вміст ВГ швидше відновлювався у тварин, уражених ацетаміносреном на тлі ЦД типу 2, ніж у щурів із гострим токсичним ураженням ацетаміносреном, що, ймовірно, пов'язано з більшою активацією захисних процесів.

Активність ГР і ГП у гомогенаті печінки перебувала на зниженому рівні протягом всього експерименту в 2-й та 4-й групах досліджуваних тварин. Максимальне зменшення даних показників, так само, як і вмісту ВГ, спостерігали на 1-шу добу експерименту (активність ГР стано- 
Таблиця 1 - Динаміка вмісту відновленого глутатіону (ммоль/кг), активності глутатіонредуктази (ммоль/(хв·кг)) та глутатіонпероксидази (ммоль/(хв· кг)) у гомогенаті печінки щурів за умов гострого токсичного ураження ацетамінофеном на тлі цд типу 2 ( $M \pm m, n=10)$

\begin{tabular}{|c|c|c|c|c|}
\hline \multirow[b]{2}{*}{ Група тварин } & \multicolumn{4}{|c|}{ ЧЧСс після введення ацетамінофену, доба } \\
\hline & 1-ша & 3-тя & 5-та & 7-ма \\
\hline Контроль & \multicolumn{4}{|c|}{ 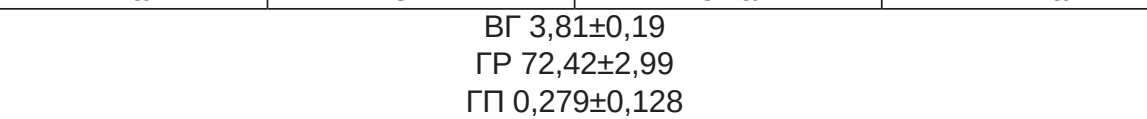 } \\
\hline \multirow{3}{*}{$\begin{array}{l}\text { Ацетамінофен } \\
\text { одноразово }\end{array}$} & ВГ 2,26士0,13* & ВГ $2,50 \pm 0,46^{*}$ & ВГ 2,66 $\pm 0,51^{*}$ & ВГ 2,76 $\pm 0,40^{*}$ \\
\hline & ГР $30,41 \pm 1,15^{*}$ & 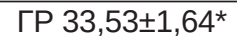 & 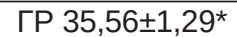 & ГР $36,73 \pm 1,99^{*}$ \\
\hline & ГП 0,095 $\pm 0,003$ & ГП 0,108 $\pm 0,026$ & ГП 0,125 $\pm 0,017$ & ГП 0,136 $\pm 0,011$ \\
\hline \multirow[t]{3}{*}{ ЦД типу 2} & ВГ $3,33 \pm 0,25$ & ВГ $3,48 \pm 0,58$ & ВГ $3,72 \pm 0,70$ & ВГ $3,93 \pm 0,61$ \\
\hline & ГР $71,55 \pm 3,74$ & ГР $74,15 \pm 3,22$ & ГР $83,49 \pm 3,73^{*}$ & ГР $87,33 \pm 3,28^{*}$ \\
\hline & ГП 0,208 $\pm 0,046$ & ГП 0,221 $\pm 0,034$ & ГП 0,236 $\pm 0,037$ & ГП 0,250 $\pm 0,045$ \\
\hline \multirow{3}{*}{$\begin{array}{l}\text { Ацетаміносрен } \\
\text { на тлі Цд типу } 2\end{array}$} & ВГ $1,25 \pm 0,20^{*}$ & ВГ $1,38 \pm 0,30$ & ВГ $1,48 \pm 0,30$ & ВГ $1,71 \pm 0,29^{*}$ \\
\hline & ГР 27,59 $\pm 1,45$ & 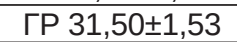 & 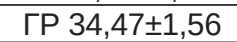 & ГР 36,35 $\pm 2,02$ \\
\hline & 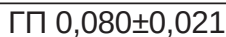 & ГП 0,093 $\pm 0,021$ & ГП 0,109 $\pm 0,021$ & ГП 0,122 $\pm 0,023$ \\
\hline
\end{tabular}

Примітка. Тут і в таблиці 2: * - різниця достовірна відносно контрольних тварин.

вила 42,0 та 38,1 \% відповідно, активність ГП 34,1 і 28,7 \% відповідно). Як свідчать отримані результати, ГП зазнала більшої інактивації, ніж ГР. У тварин 3-ї групи активність глутатіонредуктази на 1-шу добу зменшилася на 1,2 \%, а на 3-тю, 5-ту та 7-му доби даний показник збільшився на 2,4, 15,3 і 20,6 \%. Активність глутатіонпероксидази в цій групі тварин була знижена на 1-шу добу експерименту на 25,4 \%, на 3-тю - на $20,8 \%$, на 5-ту - на 15,4 \% та на 7-му - на 10,4 \%, що свідчить про поступове відновлення активності фрерменту.

Як і в першій серії експериментів, у другій серії в тварин, яким вводили ацетамінофен у максимальній терапевтичній дозі протягом 7 діб, було відмічено, що впродовж 7 діб активність глутатіонпероксидази, глутатіонредуктази та вміст відновленого глутатіону (табл. 2) зменшувалися відносно контрольних тварин протягом усього експерименту.

Як видно з таблиці 2, вміст ВГ у кожній дослідній групі у всі доби експерименту зазнавав зниження, тільки зростання даного показника відзначали у 2-й та 3-й групах на 7-му добу - на 3,1 і 4,4\%.

Отримані результати показують, що активність ГР та ГП активно знижувалася при введенні ацетамінофену у вищій терапевтичній дозі на тлі ЦД типу 2, ці зміни були менш виражені, ніж при гострому токсичному ураженні ацетамінофреном на тлі ЦД типу 2.

Таблиця 2 - Динаміка вмісту відновленого глутатіону (ммоль/кг), активності глутатіонредуктази (ммоль/(хв·кг)) та глутатіонпероксидази (ммоль/(хв·кг)) у гомогенаті печінки щурів

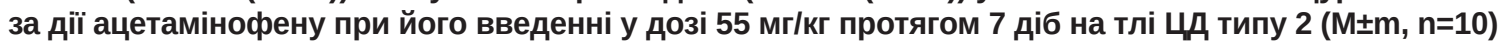

\begin{tabular}{|c|c|c|c|c|}
\hline \multirow{2}{*}{ Група тварин } & \multicolumn{4}{|c|}{ ЧЧСс після введення ацетамінофену, доба } \\
\hline & 1-ша & 3-тя & 5-та & 7-ма \\
\hline Контроль & \multicolumn{4}{|c|}{ 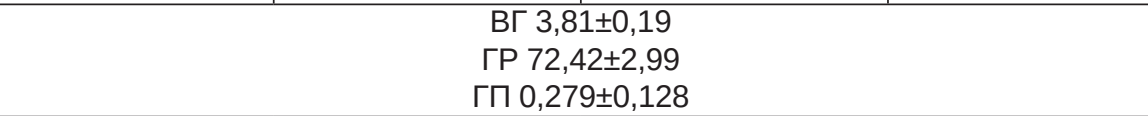 } \\
\hline \multirow{3}{*}{$\begin{array}{l}\text { Ацетаміносен } \\
7 \text { діб }\end{array}$} & ВГ $3,31 \pm 0,19$ & ВГ $3,53 \pm 0,45$ & ВГ 3,73 $\pm 0,61$ & ВГ $3,98 \pm 0,53$ \\
\hline & 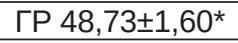 & ГР $51,27 \pm 1,29 *$ & 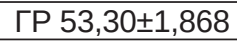 & ГР $57,57 \pm 2,42^{*}$ \\
\hline & 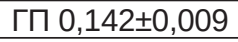 & ГП 0,153 $\pm 0,016$ & $Г П 0,171 \pm 0,023$ & $Г П 0,182 \pm 0,020$ \\
\hline \multirow[t]{3}{*}{ ЦД типу 2} & ВГ 3,33 $\pm 0,25$ & ВГ $3,48 \pm 0,58$ & ВГ $3,72 \pm 0,70$ & ВГ $3,93 \pm 0,61$ \\
\hline & 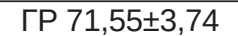 & ГР 74,15 $\pm 3,22$ & 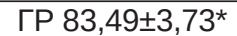 & ГР $87,33 \pm 3,28^{*}$ \\
\hline & ГП 0,208ะ0,046 & ГП 0,221 $\pm 0,034$ & ГП 0,236 $\pm 0,037$ & 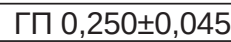 \\
\hline \multirow{3}{*}{$\begin{array}{l}\text { Ацетаміносрен } \\
\text { на тлі Цд типу } 2\end{array}$} & ВГ $3,01 \pm 0,34$ & ВГ $3,11 \pm 0,40$ & ВГ $3,27 \pm 0,52$ & ВГ $3,40 \pm 0,62$ \\
\hline & ГР 46,78 $\pm 2,23$ & ГР 48,23 $\pm 2,07$ & 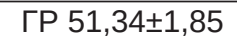 & ГР 52,94 $\pm 2,38$ \\
\hline & ГП 0,109 $\pm 0,026$ & ГП 0,126 $\pm 0,026$ & 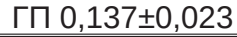 & $Г П 0,153 \pm 0,039$ \\
\hline
\end{tabular}

ВИСНОВОК. Результати проведених досліджень свідчать про те, що отруєння ацетамінофеном на тлі цукрового діабету типу 2 спричиняє істотне порушення компенсаторних механізмів, особливо стану фрерментної та неферментної ланок антиоксидантної системи. 


\section{СПИСОК ЛІТЕРАТУРИ}

1. Гонський Я. І. Вплив гістидину на активність деяких антиоксидантних ферментів крові тварин різного віку з хімічним ураженням печінки / Я. І. Гонський, М. М. Михалків // Наук. вісн. ЧНУ. Серія “Біологія". - 2001. - Вип. 126. - С. 53-58.

2. Гонський Я. І. Вплив гістидину та його металокомплексів на стан глутатіонової системи тварин різного віку з хімічним ураженням печінки / Я. І. Гонський, М. М. Михалків // Наук. записки Терноп. держ. пед. ун-ту. Серія “Біологія". - 2000. - № 4 (11). C. 63-67.

3. Глушко Л. В. Використання парацетамолу в комплексному лікуванні хронічного панкреатиту 3 метою корекції порушень продукції інтерлейкіну-6 / Л. В. Глушко, І. Т. Гавриш // Врач. дело. - 2005. - № 4. С. 63-65.

4. Ендокринологія / за ред. П. М. Боднара. - К. : Здоров'я, 2002. - С. 207-302.

5. Вплив ацетамінофену на активність процесів ліпопероксидації і стан антиоксидантної системи статевозрілих щурів-самок на тлі тривалого застосування прогестинів та естрогенів / І. Б. Івануса, І. М. Кліщ, І. 3. Кернична, Н. А. Василишин // Мед. хімія. - 2011. - 13, № 2 (47). - С. 56-62.

6. Івануса І. Б. Вплив тіотриазоліну на деякі показники антиоксидантної системи, вільнорадикального окиснення та ендогенної інтоксикації у щурів 3 токсичним ураженням ацетамінофеном на тлі трива- лого введення естрогенів і прогестинів / І. Б. Івануса // Мед. хімія. - 2011. - 13, № 3 (48). - С. 75-80.

7. Acetaminophen toxicity in an urban county hospital / F. V. Schiodt, F. A. Rochling, D. L. Casey, W. M. Lee / New England Journal of Medicine. - 1997. 337, № 16. - P. 1112-1117.

8. Bond G. R. Population-based Incidence and outcome of acetaminophen poisoning by type of ingestion / G. R. Bond, L. K. Hite // Academic Emergency Medicine. - 1999. - 6, № 11. - P. 1115-1120.

9. Kobayashi $\mathrm{H}$. Individual diversities in interferon gamma production by human peripheral blood mononuclear cells stimulated with periodontopathic bacteria / H. Kobayashi, T. Nagasawa, M. Aramaki // J. Periodontol. Res. - 2000. - 35. - N 6. - P. 319-328.

10. Кожем'якін Ю. М. Науково-практичні рекомендації 3 утримання лабораторних тварин та роботи 3 ними / Ю. М. Кожем'якін, О. С. Хромов, М. А. Філоненко. - К. : Авіцена, 2002. - 156 с.

11. Кругликова Г. О. Глутатіонпероксидазна та глутатіонредуктазна активність печінки щурів після введення селеніту натрію/Г. О. Кругликова, Ц. М. Штутман // Укр. біохім. журн. - 1976. - 48, № 2. - С. 227-233.

12. Ellman G. L.Tissue sulfhydryl groups / G. L. Ellman // Arch. Bioch.Biophys. - 1959. - № 82. - P. 70-77.

13. Лапач С. Н. Статистические методы в медикобиологических исследованиях с использованием Excel / С. Н. Лапач, А. В. Чубенко, П. Н. Бабич. - К. : Морион, 2000. - 320 с.

\section{REFERENCES}

1. Honskyi, Ya.I., \& Mykhalkiv, M.M. (2001). Vplyv histydynu na aktyvnist deiakykh antyoksydantnykh fermentiv krovi tvaryn riznoho viku z khimichnym urazhenniam pechinky [Effect of histidine on the activity of some antioxidant blood enzymes of animals of different ages with chemical damage to the liver]. Naukovyi visnyk CHNU. Seriia: Biolohiia - Scientific Journal ChNU. Series: Biology, 126, 53-58 [in Ukrainian].

2. Honskyi, Ya.I., \& Mykhalkiv, M.M. (2000). Vplyv histydynu ta yoho metalokompleksiv na stan hlutationovoi systemy tvaryn riznoho viku z khimichnym urazhenniam pechinky [Effect of histidine and its metal complexes on the state of the glutathione system of animals of different ages with chemical damage to the liver]. Naukovi zapysky Ter. derzh. ped. un-tu. Seriia: Biolohiia Scientific Notes of Ternopil State Pedagogical University. Series: Biology, 4 (11), 63-67 [in Ukrainian].

3. Hlushko, L.V., \& Havrysh, I.T. (2005). Vykorystannia paratsetamolu $v$ kompleksnomu likuvanni khronichnoho pankreatytu z metoiu korektsii porushen produktsii interleikinu-6 [Use of paracetamol in the complex treatment of chronic pancreatitis in order to correct interleukin-6 production disorders]. Vrachebnoe delo - Doctor's Business, 4, 63-65 [in Ukrainian].
4. Bodnar, P.M. (Ed.). (2002). Endokrynolohiia [Endocrinology]. Kyiv: Zdorovia [in Ukrainian]

5. Ivanusa, I.B., Klishch, I.M., Kernychna, I.Z., \& Vasylyshyn, N.A. (2011). Vplyv atsetaminofenu na aktyvnist protsesiv lipoperoksydatsii i stan antyoksydantnoi systemy statevozrilykh shchuriv-samok na tli tryvaloho zastosuvannia prohestyniv ta estroheniv [Effect of acetaminophen on the activity of lipoperoxidation processes and the state of the antioxidant system of sexually mature female rats on the background of prolonged use of progestins and estrogens]. Medychna khimiia - Medical Chemistry, 2, 56-62 [in Ukrainian].

6. Ivanusa, I.B. (2011). Vplyv tiotryazolinu na deiaki pokaznyky antyoksydantnoi systemy, vilnoradykalnoho okysnennia ta endohennoi intoksykatsii u shchuriv z toksychnym urazhennyam atsetaminofenom na tli tryvaloho vvedennia estroheniv i prohestyniv [Influence of tiotriazolin on some indicators of antioxidant system, free radical oxidation and endogenous intoxication in rat with toxic damage by acetaminophen against prolonged administration of estrogens and progestins]. Medychna khimiia - Medical Chemistry, 3, 75-80 [in Ukrainian].

7. Schiodt, F.V., Rochling, F.A., Casey, D.L., \& Lee, W.M. (1997). Acetaminophen toxicity in an urban 
county hospital. New England Journal of Medicine, 337 (16), 1112-1117.

8. Bond, G.R., \& Hite, L.K. (1999). Population-based Incidence and outcome of acetaminophen poisoning by type of ingestion. Academic Emergency Medicine, 6 (11), 1115-1120.

9. Kobayashi, H., Nagasawa, T., \& Aramaki, M. (2000). Individual diversities in interferon gamma production by human peripheral blood mononuclear cells stimulated with periodontopathic bacteria. J. Periodontol. Res. 35 (6), 319-328.

10. Kozhemiakin, Yu.M., Khromov, O.S., \& Filonenko, M.A. (2002). Naukovo-praktychni rekomendatsii z utrymannia laboratornykh tvaryn ta roboty z nymy [Scientific and practical recommendations for the mainte- nance of laboratory animals and work with them]. Kyiv: Avitsena [in Ukrainian].

11. Kruhlykova, H.O., \& Shtutman, Ts.M. (1976). Hlutationperoksydazna ta hlutationreduktazna aktyvnist pechinky shchuriv pislia vvedennia selenitu natriiu [Glutathione peroxidase and glutathione reductase activity of rat liver after administration of sodium selenite]. Ukr. biokhim. zhurn. - Ukrainian Biochemical Journal, 48 (2), 227-233.

12. Ellman, G.L. (1959). Tissue sulfhydryl groups. Arch. Bioch. Biophys., 82, 70-77.

13. Lapach, S.N., Chubenko, A.V., \& Babych, P.N. (2000). Statisticheskie metody $v$ mediko- biologicheskikh issledovaniyakh s ispolzovaniyem Excel [Statistical methods in medical-biological research using Excel]. Kyiv: Morion [in Ukrainian].

\section{ТЕРНОПОЛЬСКИЙ ГОСУДАРСТВЕННЫЙ МЕДИЦИНСКИЙ УНИВЕРСИТЕТ ИМЕНИ И. Я. ГОРБАЧЕВСКОГО \\ ВЛИЯНИЕ ПОРАЖЕНИЯ АЦЕТАМИНОФЕНОМ НА ФОНЕ САХАРНОГО ДИАБЕТА ТИПА 2 НА ИЗМЕНЕНИЯ ПОКАЗАТЕЛЕЙ ГЛУТАТИОНОВОЙ СИСТЕМЫ}

\section{Резюме}

Вступление. Важнейшей фрункцией печени в организме является нейтрализация и обезвреживание токсичных веществ. Метаболизм и утилизацию химических и биологических токсинов осуществляет обезвреживающая система гепатоцитов с последующим выведением вредных продуктов из организма.

Цель исследования - изучить влияние ацетаминофена на фроне сахарного диабета типа 2 на основные параметры глутатионового звена антиоксидантной системы в гомогенате печени крыс во временной динамике.

Методы исследования. Опыты проводили на белых половозрелых крысах массой тела 180-220 2, которых содержали на стандартном рационе вивария при свободном доступе к воде. Было выполнено 2 серии экспериментов. В первой токсическое поражение ацетаминофреном вызвали путем однократного внутрижелудочного введения животным суспензии ацетаминофена в 2 \% растворе крахмала в дозе 1250 мг/кг массы тела (1/2 LD 50 ), во второй - суспензии ацетаминофена в 2 \% растворе крахмала в дозе 55 мг/ка, что соответствует высшей терапевтической дозе, в течение 7 суток. Негенетическую форму экспериментального сахарного диабета типа 2 моделировали по методике S. Islam, H. Choi (2007)

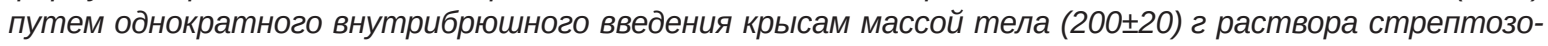
тоцина ("Sigma”, США) из расчета 65 мг/ка, который разводили цитратным буфрером (рН 4,5), с предварительным (за 15 мин) интраперитонеальным введением никотинамида в дозе 230 мг/ка. Для контрольной группы использовали крыс с той же массой тела, которым вводили аналогичный объем растворителя (цитратный буфрер с рН 4,5).

Результаты и обсуждение. Активация реакций липидной пероксидации является одним из фрундаментальных биологических механизмов повреждения биоструктур и развития клеточной патологии при действии повреждающих фракторов различного генеза, особенно в условиях действия ксенобиотиков.

Вывод. Отравление ацетаминофеном на фроне сахарного диабета типа 2 вызывает существенное нарушение компенсаторных механизмов, особенно состояния фрерментного и нефрерментного звеньев антиоксидантной системы.

КЛЮЧЕВЫЕ СЛОВА: ацетаминофен; восстановленный глутатион; глутатионпероксидаза; глутатионредуктаза; сахарный диабет. 


\section{CHANGES IN THE INDICES OF THE GLUTATHIONE SYSTEM IN RATS WITH TOXIC DAMAGE TO ACETAMINOPHEN ON THE BACKGROUND OF TYPE 2 DIABETES MELLITUS}

\section{Summary}

Introduction. The most important function of the liver in the body is neutralization and destruction of toxic substances. Metabolism and utilization of chemical and biological toxins are carried out by neutralizing the hepatocyte system, followed by the removal of harmful products from the body.

The aim of the study - to investigate the effect of acetaminophen on the background of type 2 diabetes mellitus on the main parameters of the glutathione unit of the antioxidant system in rat liver homogenate in time dynamics.

Research Methods. The experiments were carried out on white mature rats weighing 180-220 g, contained on a standard ration of the vivarium and free access to water. We conducted 2 series of experiments. In the first, toxic acetaminophen was caused by a single intraventricular injection of acetaminophen in $2 \%$ starch solution at a dose of $1250 \mathrm{mg} / \mathrm{kg}$ body weight (1/2 LD $D_{50}$, in the second suspension of acetaminophen in a $2 \%$ starch solution at a dose of $55 \mathrm{mg} / \mathrm{kg}$, which corresponds to the highest therapeutic dose for 7 days. The non-genetic form of experimental type 2 diabetes mellitus was modeled according to the method of Islam S., Choi H. (2007) by a single intraperitoneal

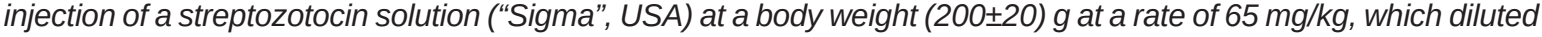
with citrated buffer ( $\mathrm{pH}$ 4.5) with a preliminary (within 15 minutes) intraperitoneal administration of nicotinamide in a dose of $230 \mathrm{mg} / \mathrm{kg}$. For the control group, rats with the same body weight were administered with a similar volume of solvent (citrate buffer $\mathrm{pH}$ 4.5).

Results and Discussion. Activation of lipid peroximation reactions is one of the fundamental biological mechanisms of damage to biostructures and the development of cellular pathology for the actions of damaging factors of various genesis, especially under the conditions of xenobiotics.

Conclusion. Acetaminophen poisoning against type 2 diabetes mellitus causes a significant disruption of compensatory mechanisms, especially the state of the enzyme and non-enzyme links of the antioxidant system.

KEY WORDS: acetaminophen, reduced glutathione, glutathione peroxidase, glutathione reductase, diabetes mellitus.

Отримано 05.05.17

Адреса для листування: О. Б. Фурка, Тернопільський державний медичний університет імені I. Я. Горбачевського, майдан Волі, 1, Тернопіль, 46001, Україна, e-mail: furkaob@tdmu.edu.ua. 